\title{
The Challenge of Oil Spill Monitoring and Control in Nigeria
}

\section{Chris Ikporukpo}

Department of Geography, Faculty of the Social Sciences, University of Ibadan, Ibadan, Nigeria

\section{Email address:}

coikporukpo@yahoo.com

\section{To cite this article:}

Chris Ikporukpo. The Challenge of Oil Spill Monitoring and Control in Nigeria. International Journal of Environmental Monitoring and Analysis. Vol. 8, No. 6, 2020, pp. 202-207. doi: 10.11648/j.ijema.20200806.14

Received: November 26, 2020; Accepted: December 11, 2020; Published: December 28, 2020

\begin{abstract}
Oil has been a fundamental enabler of development. Be this as it may, the emergence of the green environment movement, catalyzed by the challenge of climate change, has called into question the significance of crude oil as a source of energy. This has necessitated the need to manage the environmental impact of oil. One area needing attention is oil spill monitoring and control. Several technological systems have been developed in order to monitor and subsequently control oil spills. These include acoustic emission sensoring, infrared sensoring, fibre optic sensoring, satellite remote sensoring and remotely-piloted aircrafts. Nigeria, where oil spill is a major challenge, requires an effective management of oil spills. In realization of this, regulatory agencies such as National Oil Spill Detection and Response Agency and detailed guidelines for effective oil spill monitoring and control have emerged. Be this as it may, weak regulation by government agencies has been exploited by oil companies and communities; resulting in frequent oil spills, large quantities of spilled oil, extensiveness of polluted areas and persistence of the impact of spilled oil. Oil spills occur frequently. For instance, there were 5,848 incidents resulting in the spillage of about 169,691 barrels of oil between 2010 and 2018. Spills occur in all parts of the oil producing region, the Niger Delta; resulting in its being commonly described as the most polluted area of the planet. The impact of spills is usually enduring because many spill sites are either not cleaned or cleaned ineffectively. Effective regulation and a more environment-friendly oil spill monitoring and control through technological applications are necessary.
\end{abstract}

Keywords: Oil Spills, Spill Monitoring, Spill Control, Challenge of Spill Management, Nigeria

\section{Introduction}

Crude oil is a very environment-unfriendly natural resource; for, all the stages of its value chain, from exploration to final use, are characterized by a potential for pollution. This is why there is a determined effort, informed by the challenge of climate change, to replace it as a source of energy. In some settings, its exploitation is resisted by environmental activists and indigenous people because of the issue of environmental unfriendliness. A good example is the continuing resistance to oil exploitation in the Arctic National Wildlife Refuge of Alaska, USA [1], in spite of attempts by recent Republican Presidents, particularly Donald Trump, to drill for oil in the protected area.

Given the circumstance, comprehensive environmental impact assessments and effective environmental monitoring and control are fundamental in the oil industry. One critical aspect of environmental monitoring and control is oil spill monitoring and control. Given the fact that oil spills cannot be totally eliminated, monitoring to ensure that where they occur, they are promptly controlled is absolutely necessary. It is this realization that has informed the establishment of effective monitoring and control systems by various countries, based on increasingly complex research effort. From the rudimentary visual inspection approach, there have been several technological developments such as acoustic emission sensoring, infrared sensoring, fibre optic sensoring [2], Satellite remote sensing [3] and remotely piloted aircraft $[4,5]$. These new technologies have been employed in such countries as Russia [6], Libya [7], Abu Dhabi [8], and the EU where spill response has been of considerable interest. [9].

The developments in oil spill monitoring and control have been such that technology has emerged as a critical factor. Be this as it may, the most fundamental determinant of success in any setting is the organisational framework which depends on several variables such as social, political and economic inputs. It is therefore to be expected that oil spill monitoring and control systems will vary from one country to another. This paper examines the setting in Nigeria which is a major 
oil producer and exporter. It analyzes the organisational framework for oil spill monitoring and control, the extent to which the monitoring and control functions are effectively discharged and the emergent challenges.

\section{Methodology}

\subsection{Study Area Context}

Nigeria, located in the south eastern coast of West Africa, is the continent's largest producer of crude oil; producing more than 2 million barrels per day. It is the $11^{\text {th }}$ leading producer globally and the $9^{\text {th }}$ in terms of export. The Niger Delta Region and its borderlands, located in the central coastal part of the country, including the coastal sea, are the centres of oil and gas production. There is a search for oil in various inland drainage basins of the country. The oil is produced by several multinational and local companies, including a national oil corporation.

A network of pipelines crisscrosses the oil producing region. There are three basic types. These are:

Crude oil pipelines;

Natural gas pipelines; and

Refined petroleum products pipelines.

The crude oil pipelines link the oilfields and the oil export terminals, from where a predominant proportion of the oil is exported. These pipeline systems are owned and operated by the producing companies, especially the multinationals. Crude oil pipelines also link some oilfields and the refineries. Three of the refineries are in the oil producing region while a fourth is in the northern city of Kaduna, more than 600 kilometres from the Niger Delta. The gas pipeline system links production centres and several gas-powered electricity stations, mainly in the southern parts of the country. The refined petroleum product pipeline system links the refineries and the import seaports on the one hand and several depots located all over the country.

Leakages and spills occur in all the three types of pipeline systems. However, the greatest challenge is in the crude oil pipeline system, which is by far much more significant than the others. It is this system which conveys the mainstay of country's economy that is the focus of this paper.

\subsection{Sources of Data}

The data were obtained from publications of Nigerian government and its establishments, oil companies operating in the country, and local and international organisations. The government establishments included the Nigerian National Petroleum Corporation (NNPC), the Department of Petroleum Resources, (DPR), the National Oil Spill Detection and Response Agency (NOSDRA) and the Central Bank of Nigeria (CBN) The Oil Companies whose publications were used included Shell Petroleum Development Company of Nigeria (SPDC), a subsidiary of Royal Dutch Shell, Chevron, Total, Exxon Mobil and Nigeria Agip Oil Company, a subsidiary of ENI. These are the major oil companies operating in the country and have joint venture agreements with the government oil company (NNPC).

The international organisations included the World Bank, United Nations Environment Programme (UNEP), United Nations Development Programme (UNDP), Amnesty International and Human Rights Watch. Environmental Rights Action/Friends of the Earth, Nigeria, a leading Nigerian environmental NGO was the local group whose publications were useful sources of information.

Three sets of data were collected. These were: (i) the structure of oil spill monitoring and control decision-making; (ii) oil spills and oil spills management activities; and (iii) challenges of oil spill monitoring and control. The first sets of data were obtained from the publications of the government and its establishments. The information sources included Acts of parliament and other publications on the oil industry. The second sets of data were more encompassing and therefore were collected from a wide range of sources. These sources included publications of DPR, NOSDRA, the various oil companies and international and local organisations. The information on the challenges was also obtained from numerous sources involving virtually all the sources of data indicated earlier.

\section{Results and Discussion}

\subsection{Framework for Monitoring and Control}

The organizational structure for the monitoring and control of oil spills involves DPR, NOSDRA, the oil companies and the communities where oil is produced and those around oil and gas pipelines. DPR and NOSDRA perform mainly regulatory functions. The main function of DPR include:

supervision of petroleum industry operations;

monitoring of petroleum industry activities to ensure compliance with national goals and aspirations;

making sure that regulations on health, safety and environment in the oil industry meet national and international standards;

advise government and its agencies on petroleum-related matters;

process applications for leases, licences and permits for petroleum activities;

ensure timely payment of rents, royalties and other revenue of the petroleum industry; and

the keeping of records on the operation of the petroleum industry.

In the context of this paper, it is the function on environmental regulation that is germane. In performing this function, DPR has been developing guidelines and standards for the oil industry since 1981 .

NOSDRA which was established in 2006 [10], in comparison with DPR, (created in 1970, with varied functions), has an environment-focused responsibility. Its main functions are:

surveillance and ensuring compliance with all existing environmental regulations in the petroleum industry;

receive reports of oil spills and coordinate oil spill 
response activities;

ensure that all oil industry operators belong to Clean

Nigeria Associates; and

coordinate the removal of hazardous and noxious substances as determined by the Federal Government.

NOSDRA is the lead agency in the management of oil spills in the country. Indeed, the Director General/Chief Executive Officer of the Agency is the "National Commander" of the National Oil Spill Contingency Plan [11].

The organs setting up DPR and NOSDRA and the document, Environmental Guidelines and Standards for the Petroleum Industry in Nigeria [12] set out the responsibility of the oil companies. The companies are expected to operate in such a way that avoids oil spills. However, if there is an oil spill in a company's operations, it is expected to report to NOSDRA and take necessary action for clean-up. These responsibilities are stated in Part III, Section 6, subsections 2 of the NOSDRA Act. As subsection 2 declared:

An oil spiller is by this Act to report an oil spill to the Agency in writing, by fax or electronic mail not later than 24 hours after the occurrence of an oil spill in default of which the failure to report shall attract penalty in the sum of $\$ 2,000,000$ for each day of the failure to report the occurrence.

Subsection 3 indicates the requirement for a clean-up and an action plan for remediation within two weeks. The penalty for liability includes a fine not exceeding $\$ 5,000,000$ or imprisonment for a term not exceeding 2 years or both.

The communities, being major stake-holders that are directly affected by spills, are expected to report such spills to NOSDRA. In practice, communities usually report to the oil company concerned. Community leaders are also expected to participate in the inspection of affected site where a spill occurs. Apart from community leaders, the joint inspection team is usually made up of NOSDRA, Oil Company and concerned environmental NGO representatives.

\subsection{The Failure of Monitoring and Control}

The perspective of local and international environmental NGOs and several other organisations and individuals, such as the United Nations Environment Programme, Amnesty International, Human Rights Watch and United Nations Development Programme, is that there is no effective oil spill monitoring and control in Nigeria [13-17]. Four indications of this may be identified. These are:

frequent occurrence of oil spills;

large quantities of oil spilled;

persistence of impact of oil spills; and

extensiveness of oil polluted areas.

Oil spills occur frequently in the country. As Amnesty International [14:11] put it, "every year, hundreds of oil spills damage the environment and devastate the lives of people living in the Niger Delta". The report by Amnesty International indicated that between 2011 and 1018, there were 1,010 spills in Shell's operational area. There were, for instance, 189 in 2011, 188 in 2012, and 181 in 2013. Similarly, Nigeria Agip Oil Company (ENI) recorded 351 in 2014, 196 in 2015 and 165 in 2016. Indeed, an average of 5 spills per week were recorded by the two companies between 2011 and 2017. Generally speaking, the spills recorded in the country are usually relatively large ones. Indeed, some of the companies do not report the very small ones. Thus, the quantity of oil spilled is enormous. Using the cases of two companies (Shell and Nigeria Agip Oil Company/ENI), Amnesty International in the same 2018 study reported that only these two companies spilled 21.7 million litres of oil, that is the equivalent of 9 olympic swimming pools, between 2011 and 2017. Shell spilled about 2.4 million litres in 2011, about 3.8 million in 2012 and about 3.4 million in 2013 . Nigeria Agip Oil Company spilled about 1.1 million litres in 2014 and about 1.8 million in 2015 .

A generalized nation-wide setting, taking into consideration all the oil producing companies, shows a clearer picture of the issues. For instance, about 546 million gallons of oil (that is about 13.37 million barrels) were spilled in the country from 1958 to 2010. In other words, about 257,142 barrels were spilled on the average annually $[17,18]$.

Table 1 shows the situation from 2010 to 2018. Although, the oil spillage challenge has decreased, it is still very significant.

Table 1. Oil Spills in Nigeria, 2010-2018.

\begin{tabular}{lll}
\hline Year & Number of Spills & Quantity of Oil Spilled (Barrels) \\
\hline 2010 & 537 & $17,658.10$ \\
2011 & 673 & $66,906.84$ \\
2012 & 844 & $17,526.37$ \\
2013 & 522 & $4,066.20$ \\
2014 & 1,087 & $10,302.16$ \\
2015 & 753 & $32,756.87$ \\
2016 & 434 & $1,658.98$ \\
2017 & 429 & $9,097.05$ \\
2018 & 569 & $9,718.22$ \\
Total & 5,848 & $169,690.79$ \\
\hline
\end{tabular}

Source: Department of Petroleum Resources, 2018 Nigerian Oil and Gas Industry Annual Report, p. 99.

The annual mean number of spills was as large as about 650 while about 18,855 barrels were spilled on the average annually.

The persistence of the impact of oil spills in spill sites and the widespread nature are also indicative of poor spill monitoring and control. The report by UNEP [13] indicated very clearly that the impact of oil spills persisted long after a spill because of inadequate attention to clean up. The setting has been such that this state of affairs was widespread. UNEP [13:9] put the situation thus:

UNEP's field observations and scientific investigations found that oil contamination in Ogoni land is widespread and severely impacting many components of the environment. Even though the oil industry is no longer active in Ogoni land, oil spills continue to occur with alarming regularity.

A combination of these factors has resulted in a situation 
where as Watts and Zalik [19] declared, "the Niger Delta is often described as the most polluted place on the planet".

It is the circumstances which have driven this situation that are examined in the next section.

\subsection{Explanation of Failure}

The preceding section has indicated that there is considerable evidence that oil spill monitoring and control in the country have not been effective. It is flaws in decision making and action that are responsible. The basic issues include:

weak government regulation;

oil company exploitation of weak regulation;

community exploitation of weak regulation; and

the challenge of technology.

The government Agencies in charge of regulating the activities in the oil industry are not effective. There are various reasons for this. The oil industry is the mainstay of the Nigerian economy; hence, government is unwilling to impose strict regulations that may discourage oil production activities. This is more so because the government, through its oil company (NNPC), has stake in all oil producing companies in the country. Furthermore, the regulating Agencies do not have the executive capacity and the financial resources to perform effectively.

The state of affairs which limits the effectiveness of the regulatory agency has been clearly expressed by UNEP [13: 139] thus:

the agency (NOSDRA) has no proactive capacity for oil spill detection and has to rely on reports from oil companies or civil society concerning the incidence of a spill. It also has very little reactive capacity - even to send staff to a spill location once an incident is reported. In the Niger Delta, helicopters or boats are needed to reach many of the spill locations and NOSDRA has no access to such forms of transport other than through the oil companies themselves. Consequently, in planning their inspection visits, the regulatory authority is wholly reliant on the oil company. Such an arrangement is inherently inappropriate.

Similarly, Olawuyi \& Tubodenyefa [20] asserted thus:

Regulatory oversight of the Nigerian oil industry is extremely weak and does not currently align with international best practices on oil sector transparency and accountability.

Given the fact that the regulatory agency is weak and almost helpless, the oil companies do not feel obliged to maintain international standards in oil spill monitoring and control. This partly explains why oil spills, as indicated earlier, are so frequent and impactful in the country. There are several dimensions of "the negligence in the Niger Delta" by oil companies, as Amnesty International [15] captioned it $[14,16]$. These include:

delay in visiting reported oil spill sites;

falsification of number and severity of oil spills;

falsification of causes of oil spills; and

ineffective clean-up and remediation of oil spill sites.

In spite of the fact that, as indicated earlier, oil companies are expected to report a spill to NOSDRA within 24 hours and take necessary action, this requirement is often breached. For instance, in the 12 January 1998, Qua Iboe spill involving more than 40,000 barrels, even by 28 January 1998, shoreline clean-up was not started and as late as March 1998, some sites were yet to be cleaned [16].

Table 2 shows how serious this delay could be; taking several months before a joint investigation visit. The implication is that spills will have more impact than they ought to be. The reasons given for such delays by the oil companies include inaccessibility of locations particularly during the rainy and flood season, prevention by the youth of communities and logistic challenges. In the case of the Qua Iboe incident, earlier referred to, the reason given by Mobil was because "staff had to train crew leaders and deliver appropriate gear to the site [16].

Table 2. The Ten Slowest Oil Spill Joint Investigation Visits.

\begin{tabular}{lllll}
\hline Company & Response time (Days) & Reported volume (Barrels) & Year & Location \\
\hline Eni & 430 & 4 & 2015 & 8 " Nimbe South-Obama flowline \\
Shell & 252 & 10 & 2016 & 20" TEP at Ugbuegungun \\
Shell & 190 & 0.2 & 2015 & 12" Imo River - Ogale Pipeline at Owaza \\
Shell & 189 & 0.4 & 2015 & Ubie Well 5S/L Flowline at Idu - Ekpeye \\
Shell & 180 & 44 & 2016 & 20" Otumara - Escravos Pipeline at Ogidigben \\
Shell & 156 & 3 & 2014 & Bonny Well 2L Flowline at Ererekiri/Okolo Launch \\
Shell & 126 & 18.84 & 2012 & 16" South Forcados Trunkline at Oviri Olomu \\
Eni & 123 & 3.2 & 2015 & Idu 11Ls Thermo Well \\
Shell & 121 & 15 & 2017 & 12" Imo River - Ogale Pipeline at Umuololo \\
Shell & 113 & 73 & 2016 & 20" Kolocreek to Rumuekpe Pipeline Riser at Aminigboko \\
\hline
\end{tabular}

Source: [15] p. 24.

The oil companies are usually accused by environmental and human rights organisations, such as Friends of the Earth Nigeria, Amnesty International and UNEP of falsifying the number of spills, quantity spilled and the causes of spills. This is the basis for Amnesty International [14] captioning its report "Bad Information: Oil Spill Investigations in the Niger
Delta”. Typically, both oil spill numbers and quantity spilled are reduced. There is also evidence that there is the tendency to ascribe the factor of sabotage even if the cause were not. The fact that oil companies do not diligently clean-up and remediate oil spill sites complicates the issue of oil spill control. As UNEP [13] asserted thus in the case of Shell: 
It is evident from the UNEP field assessment that SPDC's Post-oil spill clean-up of contamination does not achieve environmental standards according with Nigerian legislation, or indeed with SPDC's own standards. During its reconnaissance survey, UNEP came across dozens of locations where oil spill incidents had occurred in the past... The difference between a clean-up site and a site awaiting clean-up was not always obvious.

Table 3. Perceived Causes of Oil Spills in Niger Delta.

\begin{tabular}{llllll}
\hline \multirow{2}{*}{ Sample Location } & \multirow{2}{*}{ Sample size } & Percentage Response & & & \\
\cline { 3 - 6 } & & No Spill & Oil Companies Carelessness & Sabotage & Both \\
\hline Ogboloma (Elelebou) & 30 & 0.0 & 86.7 & 3.3 & 10.0 \\
Oporoma & 30 & 0.0 & 76.7 & 0.0 & 23.3 \\
Okwuzi & 30 & 3.3 & 93.3 & 0.0 & 3.3 \\
Afam-Ukwu & 31 & 0.0 & 100.0 & 0.0 & 0.0 \\
Obrikom & 34 & 0.0 & 91.2 & 2.9 & 5.9 \\
Aggregate for East & 155 & 2.6 & 89.7 & 1.3 & 8.4 \\
Afiesere & 40 & 0.0 & 35.0 & 7.5 & 55.0 \\
Olomoro & 38 & 0.0 & 36.8 & 13.2 & 50.0 \\
Oweh & 42 & 0.0 & 26.0 & 14.0 & 81.0 \\
Ozoro & 41 & 0.0 & 60.0 & 11.1 & 58.5 \\
Uzere & 45 & 0.5 & 35.9 & 9.2 & 28.9 \\
Aggregate for West & 206 & 0.6 & 59.0 & 5.8 & 54.4 \\
All Locations & 361 & & & 4.6 \\
\hline
\end{tabular}

Source: [21] P. 28.

There is no doubt that although sabotage could be wrongly indicated by the oil companies as a cause of an oil spill, some spills are caused by sabotage [21]. As Table 3 shows, even individuals in the oil producing communities reported that some oil spills are caused by sabotage. Sabotage- induced spills may be more difficult to monitor because they may not be readily reported by the communities. Oil theft usually for artisanal refineries that are found in several relatively inaccessible locations in the Niger Delta complicates the monitoring challenge. The practice usually is that the operators of such refineries break crude oil pipelines to steal what they need for the refineries. In most cases, such locations are usually difficult to access in the swamp lands of the Niger Delta. The spills that result may be left unattended to for long.

The technological challenge results from the fact that those developments referred to in the introductory section, are currently not in use in the country. Spill monitoring still depends on the traditional method of visually identifying one. As indicated earlier even the regulator, NOSDRA, does not have the required equipment necessary for effective monitoring of spills.

\section{Conclusion}

The oil industry has played a critical role in development. However, its capacity to pollute has been a critical challenge. In order to address this challenge, the monitoring and control of pollution in the exploitation of crude oil are fundamental.

Nigeria continues to face challenges in an effective management of oil spills which are common. The issues pertain to the ineffectiveness of the regulation system and the exploitation of this by various stakeholders in the oil industry. It is necessary to strengthen the regulation structure through manpower development, application of technological systems and the stringent enforcement of environment- friendly policies and regulations.

\section{References}

[1] Pelly, J. (2001) Will Drilling for Oil Disrupt the Arctic National Wildlife Refuge? Environmental Science and Technology, 240A-247A.

[2] Adegboye, M. A., Fung, W. \& Karnik, A. (2019) Recent Advance in Pipeline Monitoring and Oil Leakage Detection Technologies: Principles and Approaches. www.preprints.org.

[3] Ning, J. L. et al (2018) Analysis of Marine Oil Spill Pollution Monitoring Based on Satellite Remote Sensing Technology. Materials Science and Engineering. 392; 042045.

[4] Urbahs, A. \& Zavtkevics, V. (2019) Oil Spill Remote Monitoring By Using Remotely Piloted Aircraft. Aircraft Engineering and Aerospace Technology, 91: 648-653.

[5] Urbahs, A. \& Zavtkevics, V. (2020) Oil Spill Detection Using Multi Remote Piloted Aircraft for the Environmental Monitoring of Sea Aquatorium. Environmental and Climate Technologies 24: 1-22.

[6] Barenboim, G. M. et al. (2015) New Problems and Opportunities of Oil Spill Monitoring Systems. Proceedings of the International Association of Hydrological Sciences. 366: 64-74.

[7] Eljabri, A. \& Gallagher, C. (2013) Developing Integrated Remote Sensing and GIS Procedures for Oil Spill Monitoring on the Libyan Coast. WIT Transactions on Ecology and the Environment; 169, www.witpress.com.

[8] Harahsheh, H. A. (2016) Oil Spill Detection and Monitoring of Abu Dhabi Coastal Zone Using KOMPSAT-5 SAR Imaginery. International Archives of Photogrammetry Remote Sensing and Information Sciences XLI-B8.

[9] Jorgensen, K. S. et al. (2019) The EU Horizon 2020 Project GRACE: Integrated Oil Spill Response Actions and Environmental Effects. Environmental Science Europe, 31: 44. 
[10] Federal Republic of Nigeria (2006) National Oil Spill Detection and Response Agency (Establishment) Act 2006. Abuja.

[11] Federal Republic of Nigeria (2010) National Oil Spill Contingency Plan for Nigeria. Abuja.

[12] Department of Petroleum Resource (2002) Environmental Guidelines and Standards for the Petroleum Industry in Nigeria, 1991 (as revised). Abuja.

[13] UNEP (2011) Environmental Assessment of Ogoniland Nairobi, UNEP.

[14] Amnesty International (2013) Bad Information: Oil Spill Investigations in the Niger Delta. London.

[15] Amnesty International (2018) Negligence in the Niger Delta: Decoding Shell and ENI's Poor Record on Oil Spills London.

[16] Human Rights Watch (1999) The Price of Oil. New York.
[17] UNDP (2006) Niger Delta Human Development Report. Abuja.

[18] Francis, P., Lapin, D. \& Rossiasco, P. (2011) Securing Development and Peace in the Niger Delta: A Social and Conflict Analysis for Change. Woodrow Wilson International Center for Scholars, Washington DC.

[19] Watts, M. \& Zalik, A. (2020) Consistently Unreliable: Oil Spill Data and Transparency Discourse. The Extractive Industries and Society 7: 790-795.

[20] Olawuyi, D. S. \& Tubodenyefa, Z. (2018) Review of the Environmental Guidelines and Standards for the Petroleum Industry in Nigeria (EGASPIN). OGEES Institute, Afe Babalola University, Ado Ekiti, Nigeria.

[21] Ikporukpo, C. O. (1995) Patterns and Implications of Ruralists Awareness of Environmental Policies and Laws: A Study in Nigeria's Oil Producing Region. Ibadan, NEST/ Ford Foundation Research Project. 